\title{
УДОСКОНАЛЕННЯ НАВЧАЛЬНО-ВИХОВНОЇ РОБОТИ 3 ІНОЗЕМНИМИ СТУДЕНТАМИ НА КАФЕДРІ ФІЛОСОФІЇ ТА СУСПІЛЬНИХ ДИСЦИПЛІН
}

\author{
О. І. Пилипишин, С. В. Бондаренко \\ ДВНЗ “Тернопільський держсавний медичний університет \\ імені I. Я. Горбачевського МОЗ Украйни”
}

\section{IMPROVEMENT OF THE TEASHING-EDUCATIVE WORK WITH FOREING STUDENTS AT THE DEPARTMENT OF PHILOSOPHY AND SOCIAL STUDIES}

\author{
O. I. Pylypyshyn, S. V. Bondarenko \\ SHEI “Ternopil State Medical University by I. Ya. Horbachevsky of MPH of Ukraine”
}

\begin{abstract}
У статті розглянуті проблеми та перспективи навчання іноземних студентів на кафедрі філософії та суспільних дисциплін, проаналізовані можливі шляхи їх вирішення.
\end{abstract}

The main problems of foreign students study at the Department of Philosophy and Social Studies and possible ways of their solving were analyzed in the article.

Вступ. Як засвідчує світова практика, підготовка іноземних студентів $є$ важливою складовою частиною діяльності вищих навчальних закладів. Контингент іноземних громадян, які навчаються у вищому навчальному закладі, значною мірою впливає на підвищення його рейтингу, а також на визнання у світовій системі вищої освіти. Випускники є носіями інформації в зарубіжних країнах про конкретний навчальний заклад, а також систему освіти країни, соціокультурний потенціал держави.

Підготовка іноземних громадян посідає дуже важливе місце в системі вищої медичної освіти України. Перед багатьма студентами-іноземцями у системі освіти постають суттєві проблеми, зокрема міжкультурної взаємодії, адаптації, вибору оптимальних форм і методів навчання [1]. Отже, аналіз навчальної та виховної роботи з іноземними студентами $€$ важливим і актуальним.

Метою даної роботи є дослідження специфіки викладання історії України, історії української культури, філософії і політології іноземним студентам медичного вузу, а також особливості виховної роботи з ними, визначення характеру адаптації іноземних студентів до соціально-культурного простору України.

(응. І. Пилипишин, С. В. Бондаренко
Основна частина. Однією з важливих умов адаптації іноземних студентів в нашій країні $є$ розуміння ними особливостей функціонування й розвитку українського суспільства. У навчальному процесі таке розуміння формується за допомогою вивчення історії України і української культури, філософії, політології. У педагогічній роботі із іноземними студентами насамперед слід враховувати особливості їх адаптації в українському соціокультурному середовищі. Як правильно зазначає Л. Богиня, студент має звикнути до нових умов життя у незнайомій країні, ознайомитися з особливостями побуту i, звичайно ж, сприйняти їх [2]. Для багатьох студентів відмова від старих звичок і пристосування до нових умов життя - складний і навіть болісний процес. Викладачі зобов'язані ознайомити студентів 3 правилами поведінки в українському суспільстві, із характерними рисами історії i культури, особливостями політичного життя.

Говорячи про особливості викладання, слід підкреслити, що воно повинно бути адаптованим до навчального процесу з іноземцями. Викладання дисциплін повинно відбуватися на доступному для них рівні, бо навіть найпростіші для українців поняття і факти викликають в іноземних студентів труднощі у сприйнятті і засвоєнні. Особливо це стосується імен, географічних назв, найменувань історико-культурних 
цінностей, філософських категорій. Оскільки навчальним планом не передбачається вивчення релігієзнавства, етики та естетики, що $є$ важливими складовими культури кожного народу, курси "Історії України" та “Історії української культури” покликані об’ єднати історію культури, краєзнавство, етику, естетику, релігієзнавство. Необхідно також враховувати, що викладаються дисципліни саме студентам-медикам. Дуже важливою в процесі адаптації студентів-іноземців в нашій країні $є$ мовна проблема. Необхідно враховувати ускладнене сприйняття англійської мови, якою ведеться навчання деяких з них. Суспільні дисципліни вивчаються майбутніми лікарями на I-II курсах. Тому мовний бар'єр є дуже відчутним, а викладачі повинні знаходити допоміжні шляхи порозуміння із іноземними студентами. Необхідно враховувати, що студенти, які володіють англійською мовою, мають знання різного рівня.

Отже, викладачу необхідно подавати матеріал на доступному у мовному плані рівні, зокрема треба надавати перевагу використанню простих граматичних конструкцій, часто вживаної лексики.

Надзвичайно важливою в процесі спілкування із іноземними студентами є релігійна проблема. Вона $\epsilon$ особливо актуальною для студентів-мусульман. Студенти, які прибули на навчання з країн Африки, $\epsilon$ переважно християнами, тому різниця у релігійних поглядах і переконаннях для них не настільки відчутна. Викладач у процесі спілкування із студентамимусульманами повинен проявляти толерантність, всіляко уникати суперечок і сутичок на релігійному грунті. Адже вони можуть стати підставою для несприйняття як викладача і навчальної дисципліни.

У навчальній роботі з іноземними студентами особливу увагу слід приділяти наочним методам. Найбільш ефективним тут є метод ілюстрації, що супроводжується коментарями викладача. Так, наприклад, на заняттях з історії української культури доцільно використовувати картини художників, карти, фотодокументи, фрагменти музичних творів. Використання мультимедійних засобів навчання у професійній діяльності викладача дозволяє удосконалити зміст навчання, методи та організаційні форми навчальновиховного процесу, забезпечити високий науковий $\mathrm{i}$ методичний рівень викладання, індивідуальний підхід у навчанні та підвищити ефективність подання матеріалу. Надзвичайно багато проблем виникає із викладанням дисципліни “Філософії” на других курсах усіх факультетів. Це пов'язано, насамперед, з особливостями світосприйняття і світорозуміння іно- земців. Адже ми знаємо, що такі фактори, як віросповідання, моральні норми і принципи, духовні цінності, естетичні смаки й потреби впливають на сприйняття дисципліни “Філософія”. Зміст філософіїне може бути адекватно сприйнятий, якщо застосовувати до його засвоєння догматичні підходи повсякденного мислення. Адже філософія - це не просто сума знань або інформованість, це виважений підхід до розуміння і вирішення проблем. Філософське мислення, на відміну від повсякденної унітарності і догматизму, є принципово плюралістичним і толерантним.

Традиційно основною формою начального процесу з іноземними студентами під час вивчення філософії є лекція. Але, як показує досвід, іноземним студентам, на відміну від вітчизняних, досить важко сприймати лекції “у чистому вигляді”. Нелегко в даній ситуації і лектору, оскільки він має більше працювати на дошці, більше писати, що певною мірою скорочує об'єм часу, відведений на викладання певної теми. Як альтернатива - мультимедійні презентації, що втілюється в реальність завдяки новітньому технічному обладнанню в навчальних аудиторіях. Ми вважаємо, що одним із важливих завдань викладача активізувати самостійну роботу студента.

Невичерпний потенціал активної участі іноземних студентів у вивченні філософії має семінарське заняття. Варто зазначити, що семінар як форма організації навчальної діяльності має найвищий рейтинг популярності серед студентів-іноземців, адже процес отримання нового знання тут $є$ дещо простішим. Викладач має можливість детально пояснити складні моменти теоретичного матеріалу і створити таку атмосферу, у якій студенти захочуть висловити свої думки, використати свій інтелект, слухати і дискутувати. На нашу думку, пізнавальний інтерес $є$ одним із найголовніших стимулів інтелектуальної активності студентів у процесі вивчення філософії. Саме на його розвиток мають бути орієнтовані прийоми, методи i засоби викладання.

Важливим аспектом роботи з іноземними студентами також $\epsilon$ наявність комплексного методичного забезпечення (тексти лекцій, методичні розробки семінарських занять, питання для самоконтролю, тестові завдання, ситуаційні задачі тощо). При викладанні філософії і суспільних дисциплін найбільший ефект дає запровадження інтерактивних технологій колективно-групового навчання, тому що вони $€$ найбільш демократичними. А виховання демократичного толерантного ставлення до своїх колег по навчанню $€$ важливою ланкою навчального і вихов- 
ного процесу. Повага до людей, що належать до іншої національності, означає усвідомлення їх приналежності до людства в цілому. Обговорюючи питання про долю людства, перспективи його розвитку викладач повинен підвести студентів до усвідомлення єдності людства перед глобальними проблемами сучасності, до розуміння цінності кожної культури для народів планети [3].

В процесі вивчення дисципліни "Політологія" студенти повинні володіти категоріальним апаратом, розуміти особливості взаємодії політики з іншими сферами життя суспільства. Викладачам необхідно приділяти велику увагу використанню виховного потенціалу навчальних дисциплін в аудиторний і позааудиторний час, що сприяє формуванню світоглядних принципів, самосвідомості, моральних принципів і людської гідності.

Доцільним у роботі з іноземними студентами є проведення екскурсій, ознайомлення із експонатами краєзнавчого та художнього музеїв. Відвідування галерей, різноманітних виставок, театральних вистав, концертів є корисним для сприйняття матеріалу, що стосується розвитку сучасної культури. Викладачі кафедри філософії і суспільних наук мають досвід організації таких заходів. На кафедрі заняття зі студентами проводяться у спарених групах, що викликає певні труднощі у роботі з іноземними студентами. Проведення занять з однією групою сприяло б посиленню ефективності навчально-виховного процесу, скороченню процесу адаптації студентів у новому для них соціокультурному середовищі.

Висновки. Вдосконалення роботи викладачів кафедри з іноземними студентами потребує: ефективної підготовки студентів до заняття, одним із напрямів якої є впровадження зошита самопідготовки; врахування рівня знання студентами мови викладання на кожному етапі навчання; дотримання методу поетапного збільшення обсягу інформації, текстового матеріалу та дозування домашніх завдань; координації змісту програм і навчальних матеріалів усіх дисциплін, що викладаються на кафедрі.

\section{Література}

1. Адаменко О. В. Підготовка іноземних студентів в Україні як об'єкт педагогічних досліджень / О. В. Адаменко // Фахова підготовка іноземних громадян в Україні: сучасний стан та перспективи розвитку. -К., 2002. - С. 49-53.

2. Богиня Л. Деякі аспекти соціально-культурної адаптації іноземних студентів у процесі вивчення української

мови / Л. Богиня // Теорія і практика викладання української мови як іноземної.-Полтава, 2008. - Вип. 3.-С. 111-116.

3. Мельничук І. М. Особливості викладання курсу “Історія української культури” іноземним студентам-медикам / I. М. Мельничук, Л. М. Романишина, О. В. Яцишина // Наукові записки Тернопільського національно-педагогічного університету ім. Володимира Гнатюка. Сер. : Педагогіка. - Тернопіль, 2012.-№2.-С. 114-118.

Отримано 04.08.14 